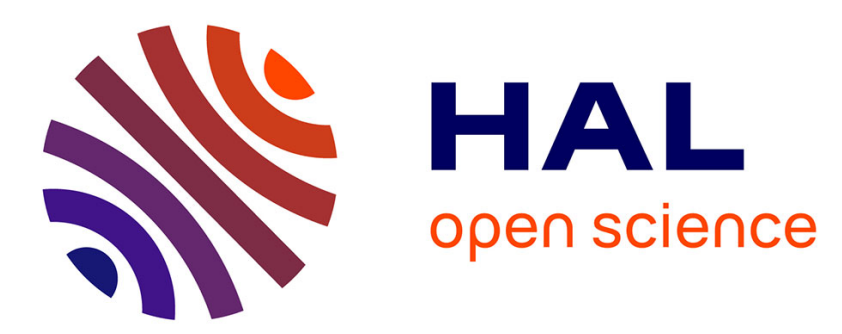

\title{
Improvement of the tribological behavior of PTFE-anodic film composites prepared on 1050 aluminum substrate
}

\author{
Julien Escobar, Laurent Arurault, Viviane Turq
}

\section{To cite this version:}

Julien Escobar, Laurent Arurault, Viviane Turq. Improvement of the tribological behavior of PTFEanodic film composites prepared on 1050 aluminum substrate. Applied Surface Science, 2012, vol. 258, pp. 8199-8208. 10.1016/j.apsusc.2012.05.022 . hal-00864926

\section{HAL Id: hal-00864926 \\ https://hal.science/hal-00864926}

Submitted on 23 Sep 2013

HAL is a multi-disciplinary open access archive for the deposit and dissemination of scientific research documents, whether they are published or not. The documents may come from teaching and research institutions in France or abroad, or from public or private research centers.
L'archive ouverte pluridisciplinaire $\mathbf{H A L}$, est destinée au dépôt et à la diffusion de documents scientifiques de niveau recherche, publiés ou non, émanant des établissements d'enseignement et de recherche français ou étrangers, des laboratoires publics ou privés. 


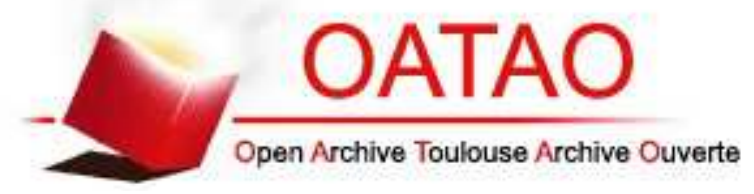

\section{Open Archive TOULOUSE Archive Ouverte (OATAO)}

OATAO is an open access repository that collects the work of Toulouse researchers and makes it freely available over the web where possible.

This is an author-deposited version published in : http://oatao.univ-toulouse.fr/ Eprints ID : 8721

To link to this article : DOI:10.1016/j.apsusc.2012.05.022

URL : http://dx.doi.org/10.1016/j.apsusc.2012.05.022

To cite this version : Escobar, Julien and Arurault, Laurent and Turq, Viviane. Improvement of the tribological behavior of PTFE-anodic film composites prepared on 1050 aluminum substrate. (2012) Applied Surface Science, vol. 258 ( $\left.{ }^{\circ} 20\right)$. pp. 8199-8208. ISSN 0169-4332

Any correspondance concerning this service should be sent to the repository administrator: staff-oatao@ listes-diff.inp-toulouse.fr 


\title{
Improvement of the tribological behavior of PTFE-anodic film composites prepared on 1050 aluminum substrate
}

\author{
Julien Escobar, Laurent Arurault*, Viviane Turq \\ Université de Toulouse, CIRIMAT, UPS/INPT/CNRS, 118 route de Narbonne, 31062, Toulouse cedex 9, France
}

Keywords:

Anodized aluminum

PTFE

Lubricating composite

Sedimentation

Friction coefficient

Tribology

\begin{abstract}
A B S T R A C T
A model anodic film was prepared to incorporate PolyTetraFluoroEthylene (PTFE) nanoparticles into the porous structure of the film. Firstly, the influence of the anodization parameters on the morphology (thickness and pore diameter) was studied, using notably FEG scanning electronic microscopy. Then, using an improved sedimentation technique, the nanoparticles were successfully inserted into the porous structure and onto its surface. EDX and Raman spectroscopy attested the presence of PTFE particles down to the bottom of the pores. Secondly, the study demonstrated the benefit of incorporating the PTFE particles. Tribological tests were also carried out and the lubricating properties of the composite analyzed. Friction coefficient curves showed a 75-fold improvement of the total lifetime of the anodic film with a reduced friction coefficient.
\end{abstract}

\section{Introduction}

Since its discovery by Buff in 1857, aluminum anodization is a process used in many fields of application like aeronautics, architecture and cookware [1]. Indeed it enables the light weight of aluminum and its alloys $\left(2.7 \mathrm{~g} / \mathrm{cm}^{3}\right)$ to be combined to specific properties such as good corrosion resistance, a wide range of coloring and an improved wear resistance.

However, anodic oxide films generally present friction coefficients of about 0.5 [2] to 1.2 [3,4]. So, it was interesting to functionalize the porous anodic film, by filling the pores with chosen particles, to enhance its lubricating properties [5]. Since 1960 , studies have thus focused on functionalizing the anodic films with PolyTetraFluoroEthylene (PTFE): either by spraying on a PTFE dispersion [6,7] or by using ultrasonic impregnation [2,8], PTFE particles remaining mainly on the top surface in both cases. More recently, Chen et al. [9] added PTFE particles to the anodization electrolyte itself in order to directly incorporate them into the composite film. Despite several studies on PTFE/anodic film composite, the insertion of PTFE particles all along the pores and its effect on tribological behavior has not been reported.

In the present paper, the first aim was to prepare a new composite (PTFE/anodic film), elaborated by filling up the pores of the anodic films with PTFE nanoparticles. Anodization was

\footnotetext{
* Corresponding author. Tel.: +33561556148.

E-mail address: arurault@chimie.ups-tlse.fr (L. Arurault).
}

performed in phosphoric acid solution, because it provides the highest pore diameter [10-12]. The second aim of this study was to show, through tribological tests, the real benefit of including PTFE particles inside the porous anodic films, the ultimate goal being to prepare an improved coating on articulated arms for spacecraft.

\section{Experimental}

\subsection{Preparation process}

The substrate material was 1050 aluminum alloy (AA). Its chemical composition in weight percent is: $<0.40 \% \mathrm{Fe},<0.25 \% \mathrm{Si}$, $<0.07 \% \mathrm{Zn}, \quad<0.05 \% \mathrm{Cu}, \quad<0.05 \% \mathrm{Mg}, \quad<0.05 \% \mathrm{Ti}, \quad<0.05 \% \mathrm{Mn}$ and $\mathrm{Al}$ accounts for the remainder.

The preparation process principally involved three successive steps: pre-treatment of the surface, anodization and functionalization by incorporation of PTFE particles inside the porous anodic films. All chemicals used were analytical grade and aqueous electrolyte solutions were prepared using deionized water.

Before anodization, the surface was pretreated according to the European Space Agency (ESA) standard (ECSS-Q-ST-7003C [13]) for space applications [14]. The aluminum sheet $(45 \mathrm{~mm} \times 37 \mathrm{~mm} \times 0.5 \mathrm{~mm})$ was degreased with ethanol and etched in mixed aqueous $\mathrm{Na}_{2} \mathrm{CO}_{3}(6.2 \mathrm{~g} / \mathrm{L})$ and $\mathrm{Na}_{3} \mathrm{PO}_{4}(12.5 \mathrm{~g} / \mathrm{L})$ solution for $5 \mathrm{~min}$ at $93 \pm 2{ }^{\circ} \mathrm{C}$. Then, the sheet was neutralized in aqueous $\mathrm{HNO}_{3}(50 \%$, v/v) for $3 \mathrm{~min}$ at room temperature. Samples were rinsed with distilled water after each step. 
The anodization was performed in an electrochemical cell, where the aluminum sheet was used as anode and a lead plate as counter-electrode. The anodization was run for a given duration (in the range $30-45 \mathrm{~min}$, usually for $34 \mathrm{~min}$ ) in the galvanostatic mode $\left(1.2<J_{\mathrm{a}}<1.5 \mathrm{~A} / \mathrm{dm}^{2}\right.$, typically $\left.1.4 \pm 0.1 \mathrm{~A} / \mathrm{dm}^{2}\right)$ using a phosphoric acid solution $(0.4 \mathrm{M})$ thermally regulated $\left(15<T<35^{\circ} \mathrm{C}\right.$, typically at $20^{\circ} \mathrm{C}$ ). To increase the anodic pore diameter, the sheet was then soaked in a cell containing a phosphoric acid solution ( $5 \mathrm{wt} \%$ ) from 0 to 30 min thermally regulated at $30^{\circ} \mathrm{C}$ [15].

Two types of PTFE aqueous dispersions (PTFE $3893^{\odot}$ and PTFE $5070^{\odot}, 60 \mathrm{wt} \%$ PTFE content for both dispersions) provided by DuPont de Nemours, were used to functionalize the porous anodic films. Industrial providers claim that the nominal average particle size for the PTFE 3893 dispersion is $220 \mathrm{~nm}$, while it is $90 \mathrm{~nm}$ for the PTFE 5070 dispersion. The anodized aluminum sheet was immersed in a beaker containing PTFE dispersion $(10-30 \mathrm{~mL})$ with the anodized face uppermost. The beaker was heated to $60^{\circ} \mathrm{C}$ and kept at this temperature until the solution was completely dry $(1-3 h)$.

\subsection{Chemical and microstructural characterizations and tribological tests}

PTFE dispersions were analyzed with a ZetaSizer Master 1000 in order to get the distribution of particle size and the zeta potential values.

Raman spectra and confocal Raman spectra were obtained with a LabRAM HR 800 Raman Spectrometer (HORIBA JOBIN YVON) with a green laser (wave length: $532 \mathrm{~nm}$ ).

The sample microstructures were observed before and after impregnation with a Field-Emission Gun Scanning Electron Microscope (FEG-SEM JEOL SM6700F device), while elementary chemical analyses were performed by energy-dispersive X-ray spectroscopy (EDX). Especially, the thickness was measured by averaging twenty measurements on FEG SEM cross-sectional views, while the pore diameter was measured by analyzing FEG SEM surface views with the free software ImageJ [16].

Frictions tests were conducted with a CSM pin-on-disc tribometer. The device was used in rotational mode, with a spherical alumina counterface of $6 \mathrm{~mm}$ in diameter and under a normal load of $1 \mathrm{~N}$, corresponding to a maximum hertzian pressure between 25 and $410 \mathrm{MPa}$, depending on the sample. The tests lasted from 5000 to 300,000 cycles. The diameter of the track is fixed to $10 \mathrm{~mm}$ with a maximal speed of movement of $5.04 \mathrm{~cm} / \mathrm{s}$. Each test was repeated at least three times.

The morphology of the counterface and the plane track after tribological testing was analyzed with a numerical microscope KEYENCE VHX 1020. The width and the depth of the substrate wear track were measured and the wear volume was calculated, using an elliptical fit of the wear profile and disregarding the wear of the counterface.

The wear volume was calculated using Eq. (1).

Wear volume $=\frac{\text { (Ellipse surface } \times \text { Perimeter of the track) }}{2}$

$$
=\frac{(D \times(W / 2) \times \pi) \times(2 \times \pi \times r))}{2}
$$

With $D$ as depth, $W$ as width and $r$ as the circle radius.

\section{Results and discussion}

\subsection{Initial PTFE dispersions}

Functionalization was conducted with two aqueous dispersions of PTFE particles (DuPont de Nemours PTFE $3893^{\odot}$ and PTFE $5070^{\odot}$ )
Table 1

Particle size and zeta potential of the dispersions.

\begin{tabular}{lll}
\hline & Particle size $(\mathrm{nm})$ & Zeta potential $(\mathrm{mV})$ \\
\hline PTFE 3893 & $220 \pm 50$ & -50 \\
PTFE 5070 & $90 \pm 40$ & -45 \\
\hline
\end{tabular}

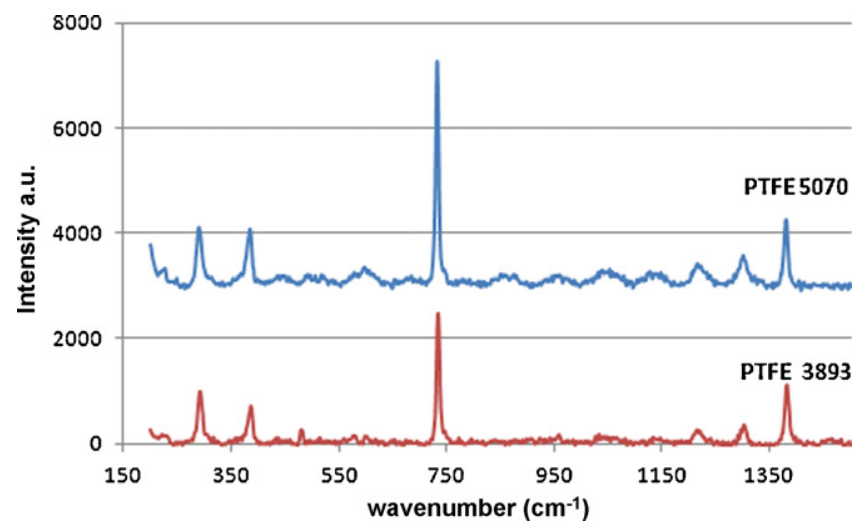

Fig. 1. Raman spectra of PTFE dispersions.

diluted in distilled water ( $0.25 \mathrm{wt} \%$ PTFE content for both dispersions after dilution). Table 1 gives the experimental values of the particle size and zeta potential.

The average values of the particle sizes ( 220 and $90 \mathrm{~nm}$ ) are in agreement with the nominal data provided by DuPont de Nemours. However, it is important to note that the standard deviation was about $23 \%$ and $44 \%$ respectively. Moreover, in both cases, the zeta potentials were negative.

The two dispersions were analyzed by Raman technique (Fig. 1). Eight identical peaks were observed on both spectra. All the bonding assignments are reported in Table 2 . The strongest peak at $733 \mathrm{~cm}^{-1}$ (noted vvs) corresponds to $\mathrm{CF}_{2}$ symmetric stretching $[17,18]$. Principal Raman bands at 290, 387, 733 and $1301 \mathrm{~cm}^{-1}$ belong to the different modes of the $\mathrm{CF}_{2}$ groups. Weak bands (noted $\mathrm{w}$, at 598 and $578 \mathrm{~cm}^{-1}$ ) were attributed to defects in the PTFE structure [19] before being attributed to $\mathrm{CF}_{3}$ deformation by Mihaly et al. [20]. Because Raman spectra are identical for both dispersions, the PTFE particles of the different size classes did not present any detectable structural differences.

\subsection{Preparation and characterization of the standard porous anodic films}

After analysis of the PTFE particles, a model anodic film was prepared with a view to obtaining a thickness of about $10 \mu \mathrm{m}$ and an average pore diameter of $200 \mathrm{~nm}$.

Before the anodization, cleaning pretreatments (degreasing, etching, neutralization) were performed. The average roughness $\left(R_{\mathrm{a}}\right)$ and peak-to-valley (PV) were measured at each step (Table 3 ).

Table 2

Assignments of the Raman peaks for the PTFE dispersions.

\begin{tabular}{ll}
\hline Raman bands & Assignment \\
\hline $290 \mathrm{~s}$ & $\mathrm{CF}_{2}$ wagging \\
$387 \mathrm{~s}$ & $\mathrm{CF}_{2}$ twisting \\
$598 \mathrm{w}$ & $\mathrm{CF}_{3}$ symmetric deformation \\
$57 \mathrm{w}$ & $\mathrm{CF}_{3}$ symmetric deformation \\
$733 \mathrm{vvs}$ & $\mathrm{CF}_{2}$ symmetric stretching \\
$1215 \mathrm{w}$ & $\mathrm{CC}_{\text {stretching }}$ \\
$1301 \mathrm{~m}, \mathrm{w}$ & $\mathrm{CF}_{2}$ asymmetric stretching \\
$1382 \mathrm{~m}$ & $\mathrm{CF}$ stretching \\
\hline
\end{tabular}



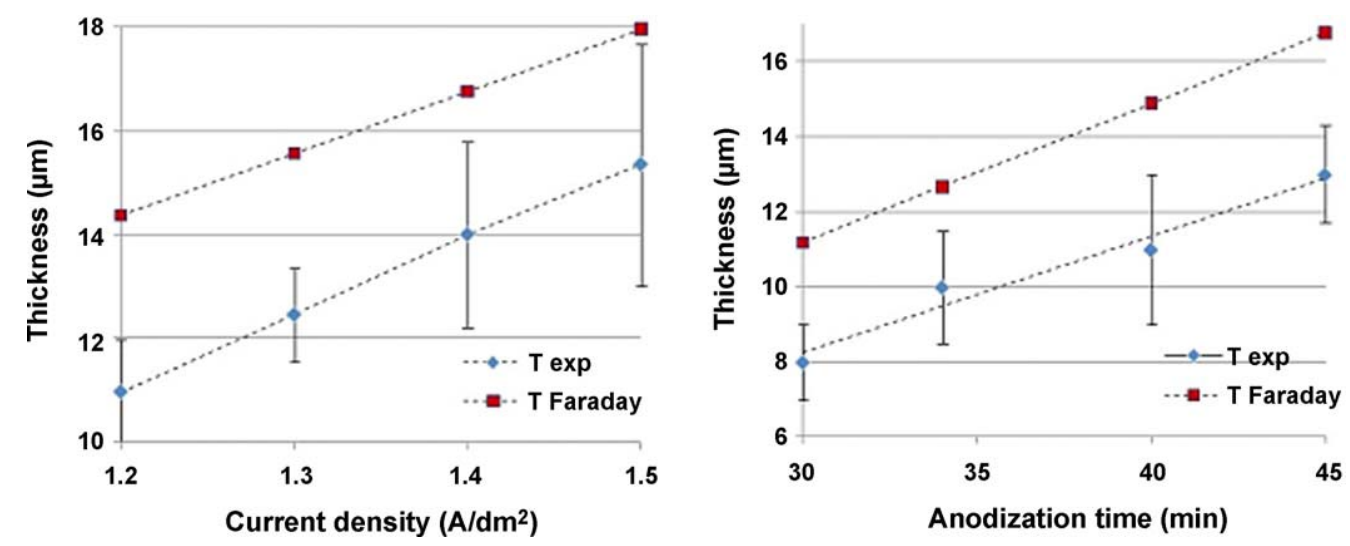

Fig. 2. Thickness of the anodic film versus current density $\left(t=45 \mathrm{~min} ; T=20^{\circ} \mathrm{C}\right)$ and versus anodization time $\left(T=20^{\circ} \mathrm{C}, J=1.4 \mathrm{~A} / \mathrm{dm}^{2}\right)$.

Table 3

Roughness and peak to valley at each step of the pretreatment of the Al substrate.

\begin{tabular}{lllc}
\hline & Degreasing & Etching & Neutralization \\
\hline$R_{\mathrm{a}}$ & $0.3 \mu \mathrm{m}$ & $0.6 \mu \mathrm{m}$ & $0.6 \mu \mathrm{m}$ \\
$\mathrm{PV}$ & $3.2 \mu \mathrm{m}$ & $8.4 \mu \mathrm{m}$ & $10.1 \mu \mathrm{m}$ \\
\hline
\end{tabular}

The roughnesses $R_{\mathrm{a}}$ and PV increased step by step along the pretreatments. The peak-to-valley measurements showed a strong difference between the "highest" and "lowest" parts on the surface of about $10 \mu \mathrm{m}$ after neutralization. This pretreated surface was then used as an anode to perform the anodization. Anodic film growth followed reaction (1) and is mainly controlled, through Faraday's law, by the current density $(J)$ and the anodizing time $(t)$.

$2 \mathrm{Al}+3 \mathrm{H}_{2} \mathrm{O} \rightarrow \mathrm{Al}_{2} \mathrm{O}_{3}+6 \mathrm{H}^{+}+6 \mathrm{e}^{-}$

We plotted the thickness of the anodic film versus the current density and the anodization time which is compared to the theoretical thickness (Fig. 2). The thickness is directly proportional to these two operational parameters, in accordance with the Faraday's law. Anyway, the experimental curves do not cross the origin because of the influence of the dissolution by the phosphoric acid. On the other hand, the anodization efficiency is about $75 \%$ in agreement with previous studies [21].

The bath temperature plotted versus the thickness and the pore diameter of the anodic film (Fig. 3 ) shows that in this temperature range $\left(15-35^{\circ} \mathrm{C}\right)$ the average pore diameter increases (from 120 to

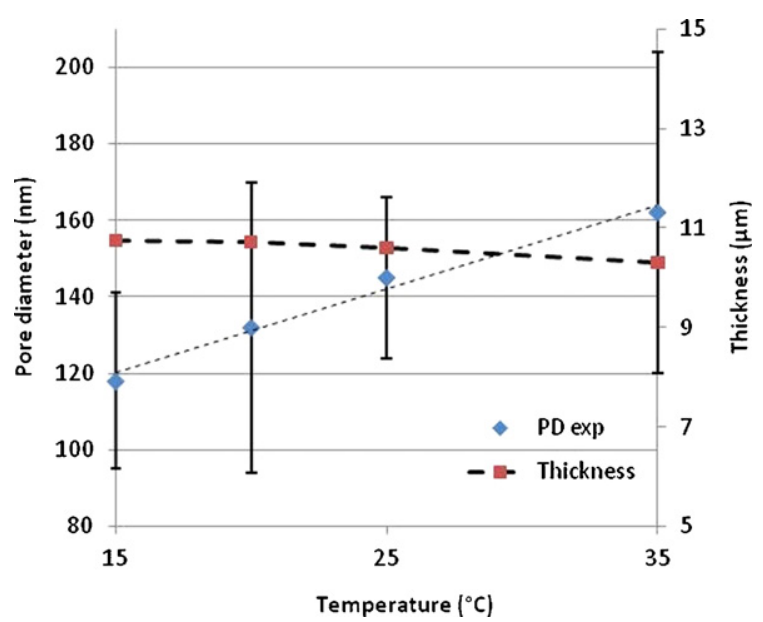

Fig. 3. Average pore diameter versus the temperature of the electrolyte $\left(J=1.4 \mathrm{~A} / \mathrm{dm}^{2}, t=45 \mathrm{~min}\right)$
$160 \mathrm{~nm}$ ) with temperature, while the thickness decreases slowly (from 10.5 to $10.0 \mu \mathrm{m}$ ).

Increasing the bath temperature increases the reaction kinetics, especially of the chemical reactions rather than the electrochemical ones. During anodization, the electrochemical growth of the anodic film is not much affected - the thickness remains almost unchanged - while chemical reaction (2) of dissolution of the anodic film in contact with the acidic electrolyte is significantly exacerbated [22].

$\mathrm{Al}_{2} \mathrm{O}_{3}+6 \mathrm{H}^{+} \rightarrow 2 \mathrm{Al}^{3+}+3 \mathrm{H}_{2} \mathrm{O}$

In a recent study, Goueffon et al. [21] also studied the thickness and the porosity of anodic films in different operational conditions. It was shown that the porosity depends on the concentration of the electrolyte, while a decrease of the thickness occurs when the temperature of the electrolyte is too high (about $30^{\circ} \mathrm{C}$ ) because of the merging of pores. However, in our study, this phenomenon was not observed in a similar range of temperatures, probably because the porosity was significantly different: here the pore diameter was $200 \pm 15 \mathrm{~nm}$ whereas in Goueffon's studies it did not reach $100 \mathrm{~nm}$.

Finally, the standard conditions chosen for the anodization were: galvanostatic mode $\left(1.4 \mathrm{~A} / \mathrm{dm}^{2}\right)$ for $34 \mathrm{~min}$, in phosphoric acid electrolyte $(0.4 \mathrm{~mol} / \mathrm{L})$ thermally regulated at $20^{\circ} \mathrm{C}$.

FEG-SEM views (Fig. 4) showed that the thickness of the standard anodic film is $10.0 \pm 0.5 \mu \mathrm{m}$ and the average pore diameter is $200 \pm 15 \mathrm{~nm}$, i.e. higher than the particle size $(90 \mathrm{~nm})$ of the PTFE 5070 dispersion and lower than the particle size $(220 \mathrm{~nm})$ of the PTFE 3893 dispersion. The pore density and porosity were respectively $5.4 \pm 1.5$ pore $\mu \mathrm{m}^{-2}$ and $17.0 \pm 2.5 \%$ for the standard anodic films.

The FEG-SEM cross-sectional view (Fig. 4) also reveals that the pores are quite erratic and far from the ideal microstructure proposed by Keller [23] due to the initial roughness of the AA substrate before anodization ( $P V=10 \mu \mathrm{m})$.

The EDX spectrum (Fig. 5) performed on the cross-section of the anodic film shows peaks attributed to the elements carbon, oxygen, and aluminum. The aluminum and oxygen directly result from the growth of the anodic film. The presence of carbon can result from carbonate inclusion from the anodization electrolyte but more probably from sample preparation and analysis by SEM.

No Raman features appear in the $100-1500 \mathrm{~cm}^{-1}$ region (Fig. 5) because of its amorphous structure [24-26]. Moreover, metallic aluminum is fluorescent. So, exciting aluminum with a laser promotes this fluorescence, and swamps any underlying Raman signal to such an extent that some elements could not be detected [27].

Tribological tests were carried out on aluminum and anodic film. Firstly, the friction coefficient of the aluminum substrate fluctuated around 0.8 (Fig. 6), a comparable value (0.85) being previously obtained for pure (99.99\%) aluminum substrate [2]. 

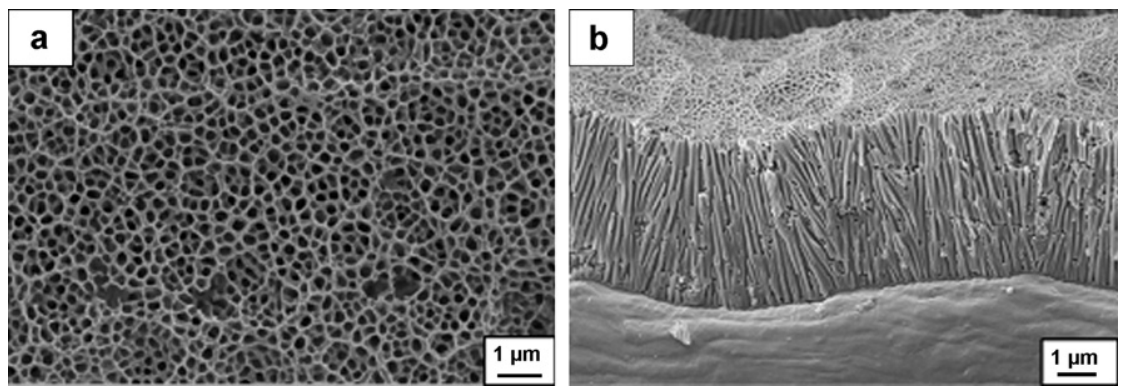

Fig. 4. FEG-SEM views (a) of the surface and (b) of the cross-section of the standard anodic film.
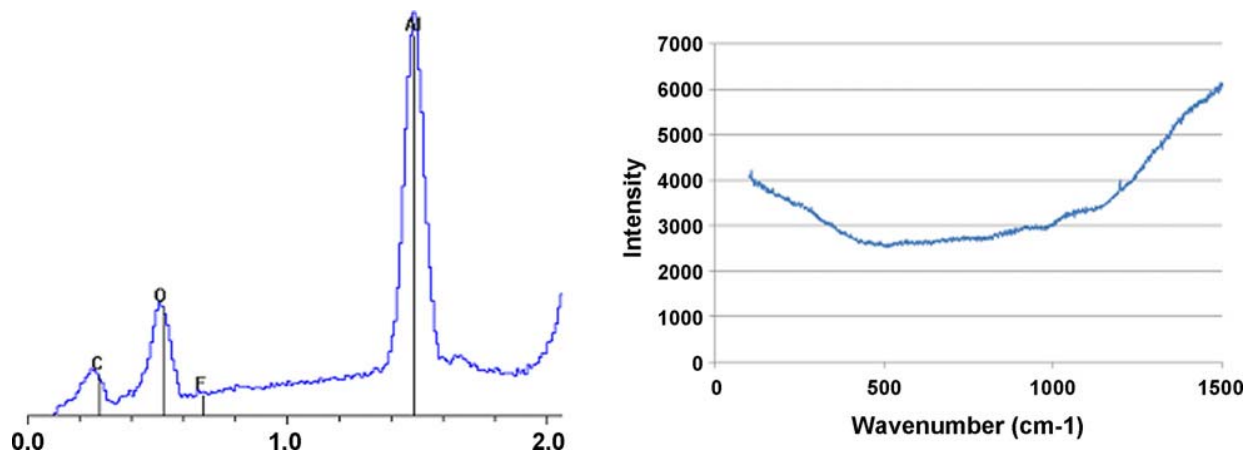

Fig. 5. EDX spectrum localized on the cross section of the anodic film and Raman spectrum of the anodic film.

Secondly, the anodized film presented a friction coefficient of about 1.10 during 3000 cycles (Fig. 6 ). After 3000 cycles, the friction coefficient decreased and reached the same value as on aluminum ( $\mu=0.70-0.80$ ). Wang [2] showed an unchanged friction coefficient (0.5-0.6) during 1500 cycles, while Kim and Choi [3,4] obtained a friction coefficient about 1.2, i.e. a value similar to ours.

The optical views of the track and the counterface after the test (Fig. 7) exhibit uncovering (exposure) of the aluminum substrate and metal transfer respectively. This shows that, at the end of the test, the anodic film was totally worn off, uncovering the aluminum substrate.

\subsection{Preparation and characterization of the composite films}

The microstructure of the anodic films after functionalization with $220 \mathrm{~nm}$-sized PTFE particles and $90 \mathrm{~nm}$-sized PTFE particles is shown in Fig. 8. The $200 \mathrm{~nm}$-sized PTFE particles remained only on the top surface of the anodic film with an average thickness

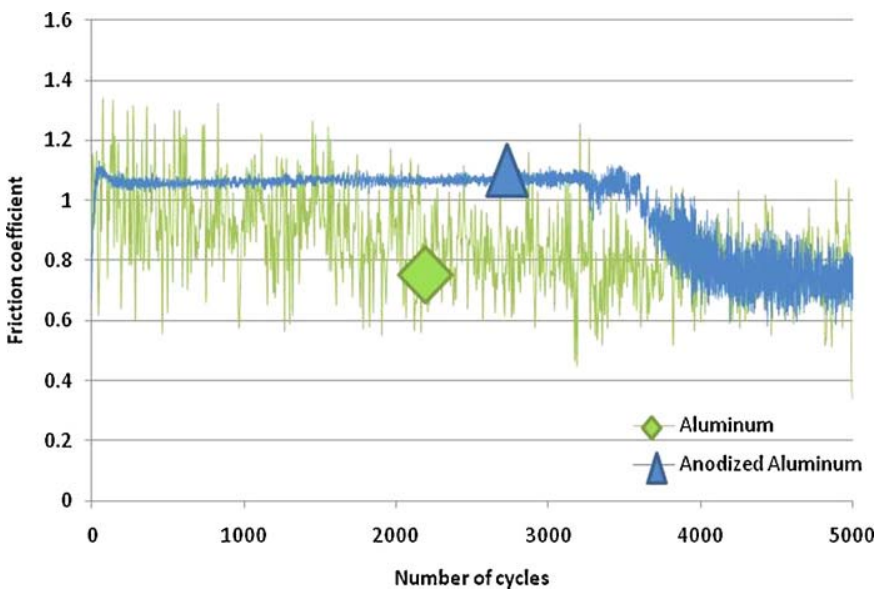

Fig. 6. Friction coefficient curves on aluminum and anodized aluminum. of $1 \mu \mathrm{m}$. The particles are larger than the average pore diameter $(200 \pm 15 \mathrm{~nm})$ and block the entrance of the pores. On the other hand, $90 \mathrm{~nm}$-sized PTFE particles are smaller than the pore diameter and were able to enter the pores reaching right down to the bottom of the structure. The pores are filled with PTFE particles and
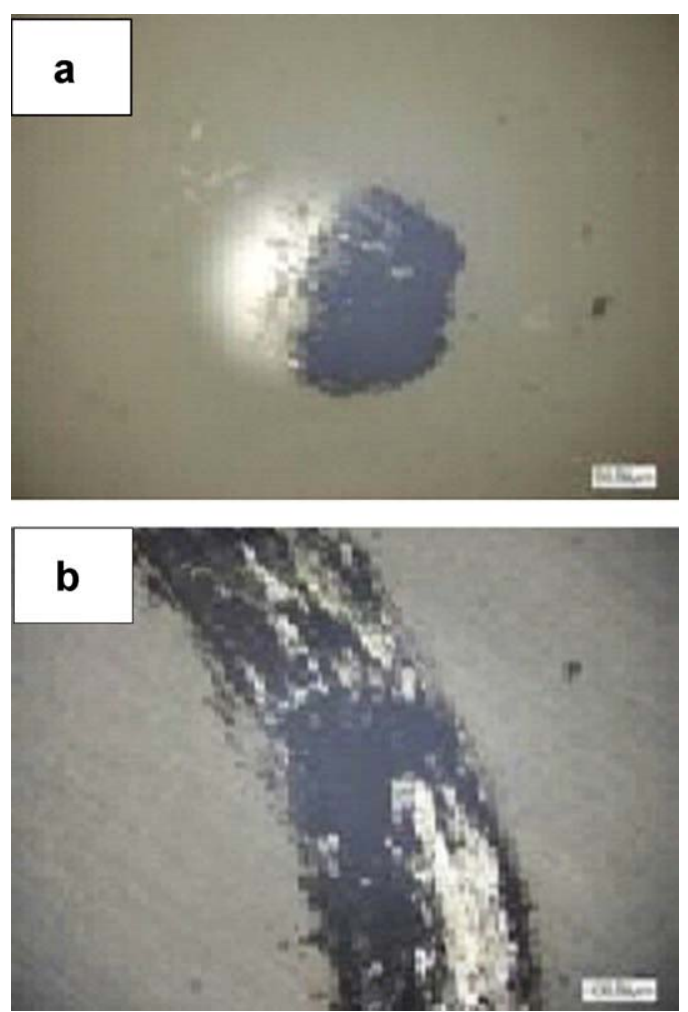

Fig. 7. Views of (a) the counterface and (b) the track at the end of the test. 

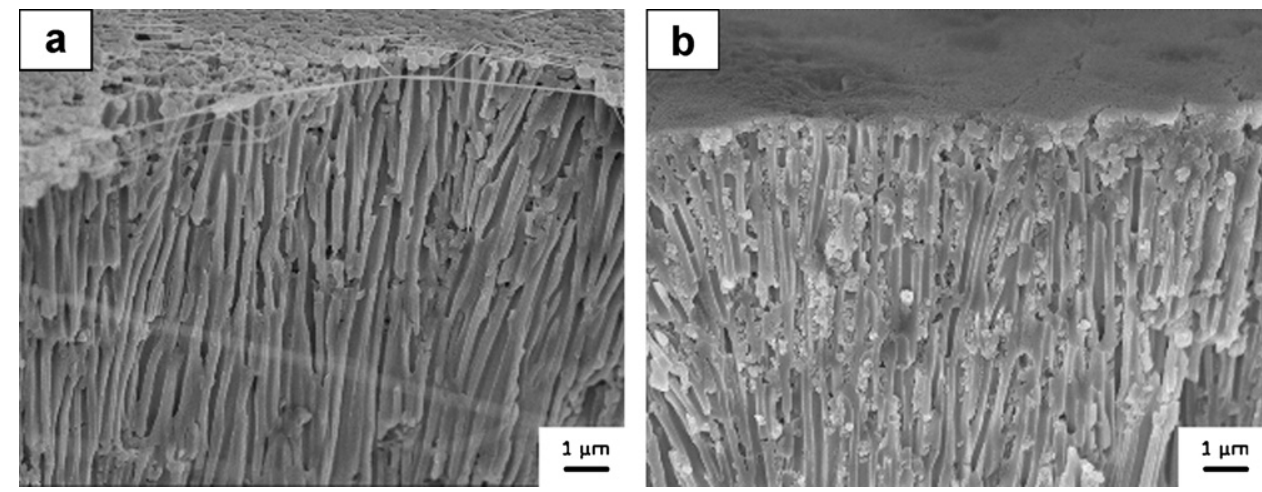

Fig. 8. FEG SEM pictures of an anodized film after drying sedimentation (a) with $220 \mathrm{~nm}$-sized PTFE particles and (b) with $90 \mathrm{~nm}$-sized PTFE particles.

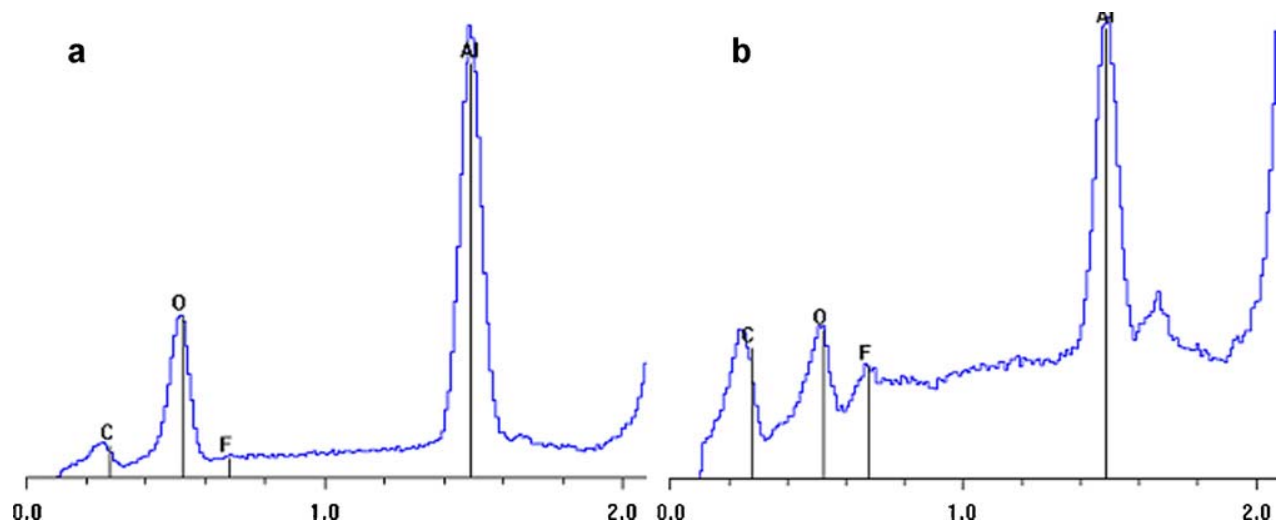

Fig. 9. EDX spectra on the cross section of the composite film functionalized (a) with $220 \mathrm{~nm}$-sized PTFE particles and (b) with $90 \mathrm{~nm}$-sized PTFE particles.

a deposit is obtained on the surface with an average thickness of $2 \mu \mathrm{m}$.

The insertion of the particles inside the anodic film and down to the bottom of the pores can be explained by two main phenomena. Firstly, when the water evaporates, PTFE nanoparticles remain in solution and led to the bottom of the pores because of the surface tension between the liquid and the gas [28], the surface tension acting as a force on the particles. In this case, the low concentration of the dispersions in PTFE ( $0.25 \mathrm{wt} \%)$ avoids flocculation of the particles before the total evaporation of the liquid. Secondly, when the liquid film is thin enough, colloidal particles can self-assemble due to attractive capillary forces driven by wetting $[29,30]$.

EDX spectra were also recorded on localized surface of the film cross sections. A spectrum of the film functionalized with $220 \mathrm{~nm}-$ sized PTFE particles is shown in Fig. 9a and with $90 \mathrm{~nm}$-sized PTFE particles in Fig. 9b. When the PTFE deposit is only on top of the surface, aluminum and oxygen peaks are mainly present (Fig. 9a) in the cross-section of the anodic film. No fluorine peaks appear, suggesting that no PTFE particles have been incorporated in the anodic film.

In contrast, when PTFE particles are on the surface and inside the porous anodic film, the aluminum and oxygen are still present (Fig. 9b), but the fluorine peak, appearing at $0.7 \mathrm{eV}$, suggests that PTFE particles have been pulled into the anodic film. This result is confirmed by comparing the intensity ratios between the peak of fluorine and the peak of aluminum for both functionalized films (Table 4).

Confocal Raman spectroscopy was also used to analyze the composition of the film at different depths, i.e. from $Z=0$ (at the initial surface) to $Z=20 \mu \mathrm{m}$ (inside the Al substrate). All the PTFE Raman bands previously observed on the dispersions (Fig. 1) are still present on the confocal Raman spectra of the functionalized anodic film. Fig. 10a shows in particular the intensity of the highest peak $\left(733 \mathrm{~cm}^{-1}\right)$ as a function of the analyzed depth of the anodic
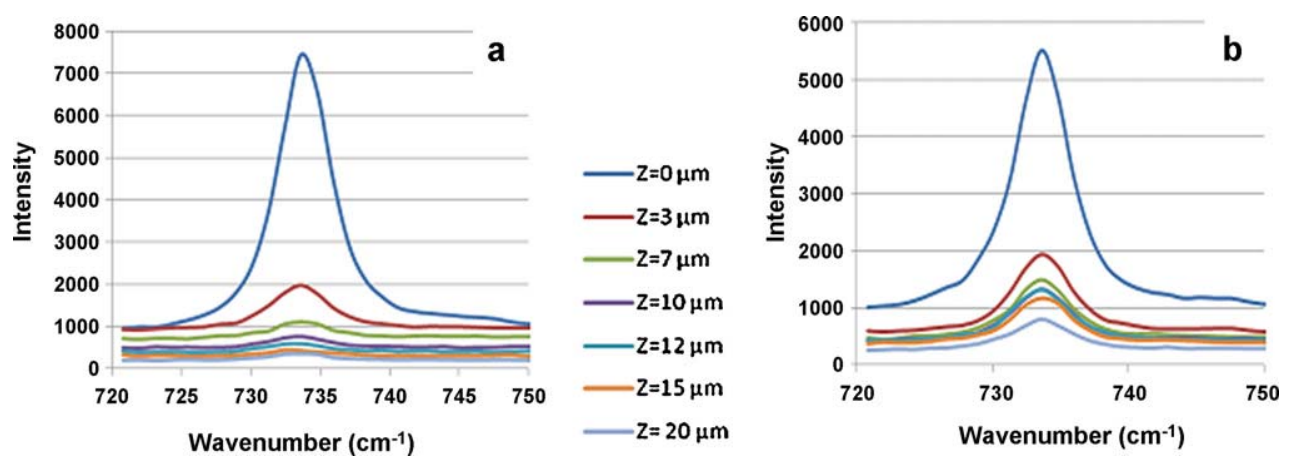

Fig. 10. Confocal Raman spectrum on anodic film with (a) PTFE on top surface and (b) PTFE inside the pores. 
Table 4

Intensity ratios between fluorine and aluminum peaks on the functionalized film.

\begin{tabular}{lll}
\hline & $\begin{array}{l}200 \mathrm{~nm} \text {-sized PTFE } \\
\text { particles }\end{array}$ & $\begin{array}{l}\text { 90 nm-sized PTFE } \\
\text { particles }\end{array}$ \\
\hline Intensity ratio $I_{\mathrm{F}} / I_{\mathrm{Al}}$ & $0.1 \%$ & $15.2 \%$ \\
\hline
\end{tabular}

film with PTFE on the surface. The intensity of the peak decreases as the analyzed zone deepens. The same remarks can be made with confocal Raman spectra on anodized film with PTFE both on the surface and inside the porous structure (Fig. 10b).

The area of the peak was then calculated at each depth to compare the decrease of peak intensity for both composite anodic films (Fig. 11). For the anodic film $(10 \mu \mathrm{m})$ with PTFE only on the top surface ( $1 \mu \mathrm{m}$, i.e. a coating thickness of about $11 \mu \mathrm{m}$ in total), the area under the peak decreased quickly and reaches a value of less than $5 \%$ for depths of $5 \mu \mathrm{m}$ to $20 \mu \mathrm{m}$. This means there are no PTFE particles inside the anodic film.

For the anodic film $(10 \mu \mathrm{m})$ with PTFE inside and on its surface ( $2 \mu \mathrm{m}$, i.e. a coating thickness of about $12 \mu \mathrm{m}$ in total), the Raman peak area also decreased. However, from depths of $3 \mu \mathrm{m}$ to $12 \mu \mathrm{m}$, almost $20 \%$ of the initial peak area still remained (Fig. 11). So, PTFE particles are significantly present in the first $12 \mu \mathrm{m}$ of anodic film. For this composite zone, it can also be noted that the peak area, corresponding to $\mathrm{CF}_{2}$ stretching, is about $20 \%$ (100\% corresponding to the pure PTFE material). This seems in good agreement with the initial porosity $(17.0 \pm 2.5 \%)$ of the anodic film. Then, from a depth of $12 \mu \mathrm{m}$ (i.e. the interface with the $\mathrm{Al}$ substrate), the peak area decreases slowly, probably because of some remaining PTFE fragments.

Thanks to the Raman spectra (Fig. 11), it can be considered that almost $15 \%$ of the volume of the composite film represents the incorporated PTFE particles. With an average particle diameter of $90 \mathrm{~nm}$ (i.e. a volume of about $3.81 \times 10^{-4} \mu \mathrm{m}^{3}$ ), the average number of particles incorporated in the anodic film ( $10 \mu \mathrm{m}$ thick) is about 700 nanoparticles per pore.

\subsection{Tribological tests on the composite film with top PTFE coating}

The anodic films, functionalized with both types of PTFE particles, or not, were tribologically tested (Fig. 12). The friction coefficient curves typically exhibit three periods (Fig. 13):

- A stable low friction coefficient period (I)

- An increase of the friction coefficient (II)

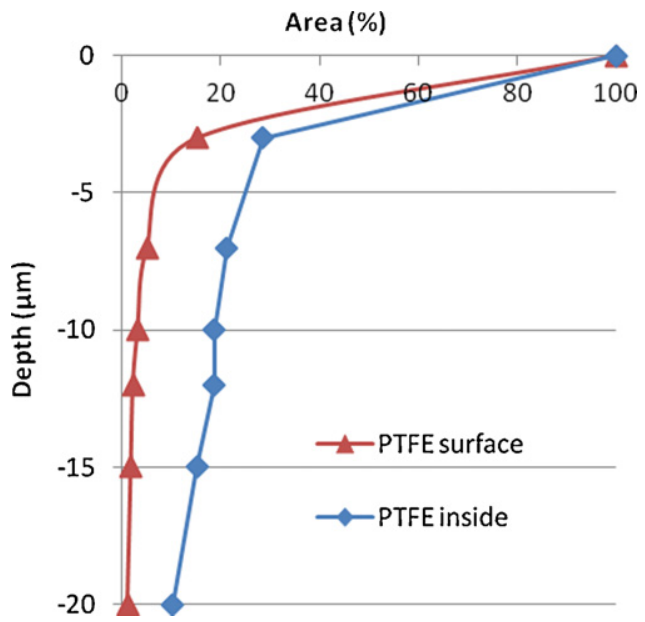

Fig. 11. Percentage of peak area versus depth for PTFE on the sample surface and PTFE inside the sample.

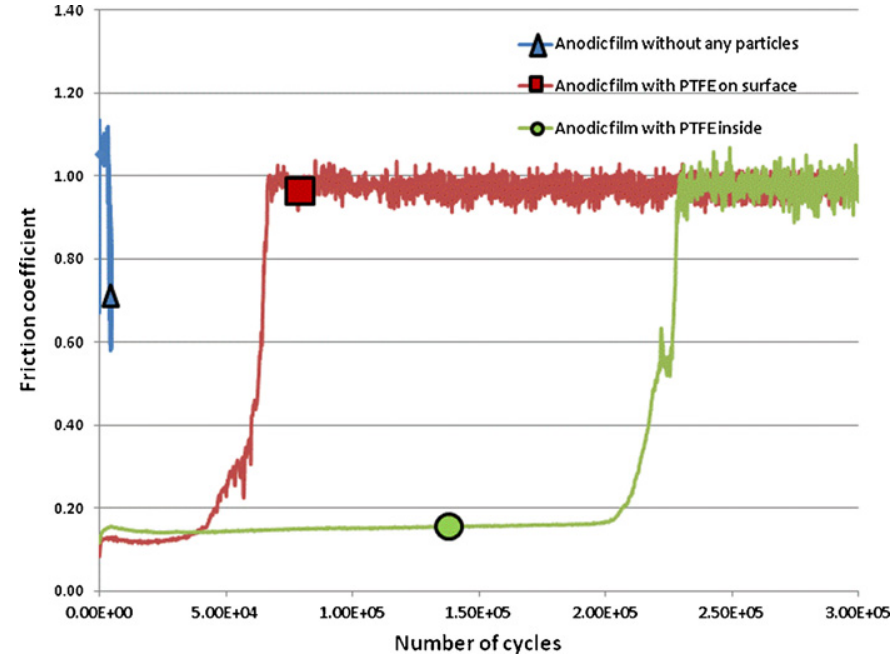

Fig. 12. Friction coefficient curves of the functionalized anodic films.

- A stable period with higher friction coefficient (III)

The friction coefficient curve corresponding to the functionalized anodic film with PTFE only on the top surface is reported in Fig. 12. During the first period of the tribological test ( 47,000 cycles), the friction coefficient was low $(\mu=0.13)$, attributed to PTFE particles alone [31] on the top surface. Then the friction coefficient increased for about 20,000 cycles and reached a value of about 0.90 . At the end, in the third period, the friction coefficient remained stable at $0.90-1.00$, i.e. at a level between the friction coefficients of aluminum $(\mu \approx 0.80)$ and anodized aluminum $(\mu \approx 1.1)$.

Optical microscopy of the track $(T)$ and the counterface $(C)$ was performed at the different periods of the test (Fig. 14).

Images $T_{1}$ and $C_{1}$ correspond to the first period of the test (after 15,000 cycles), the friction coefficient being of about 0.13 . Facies $T_{1}$ shows no oxide or metallic fragments and little wear, while PTFE can be seen on the counterface.

During the second period, while the friction coefficient increases, both track and counterface (Fig. 14) show black fragments, identified as aluminum oxide by EDX.

Finally, during the last period (friction coefficient $=0.90-1.00$ ), the aluminum substrate is exposed. Black oxide fragments are still present on the track and more fragments are on the counterface.

Table 5 presents the different characteristics of the sample, and especially an estimated wear volume at each period of the test.

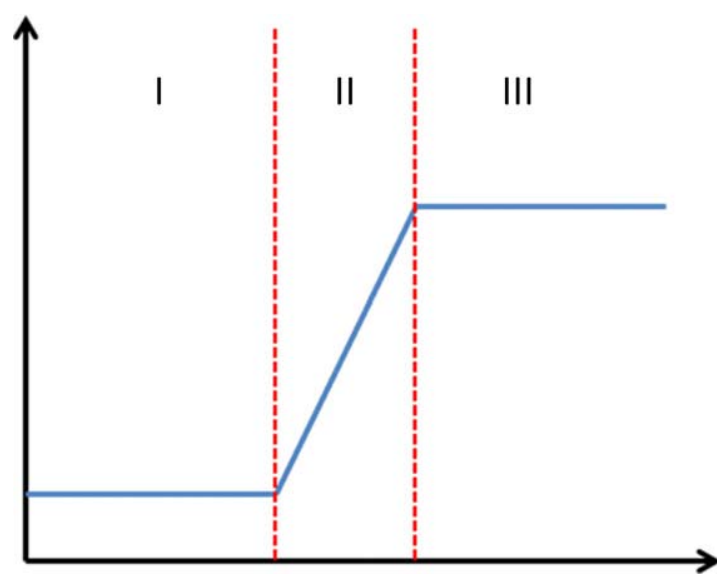

Fig. 13. Scheme of the different periods of the tribological tests. 

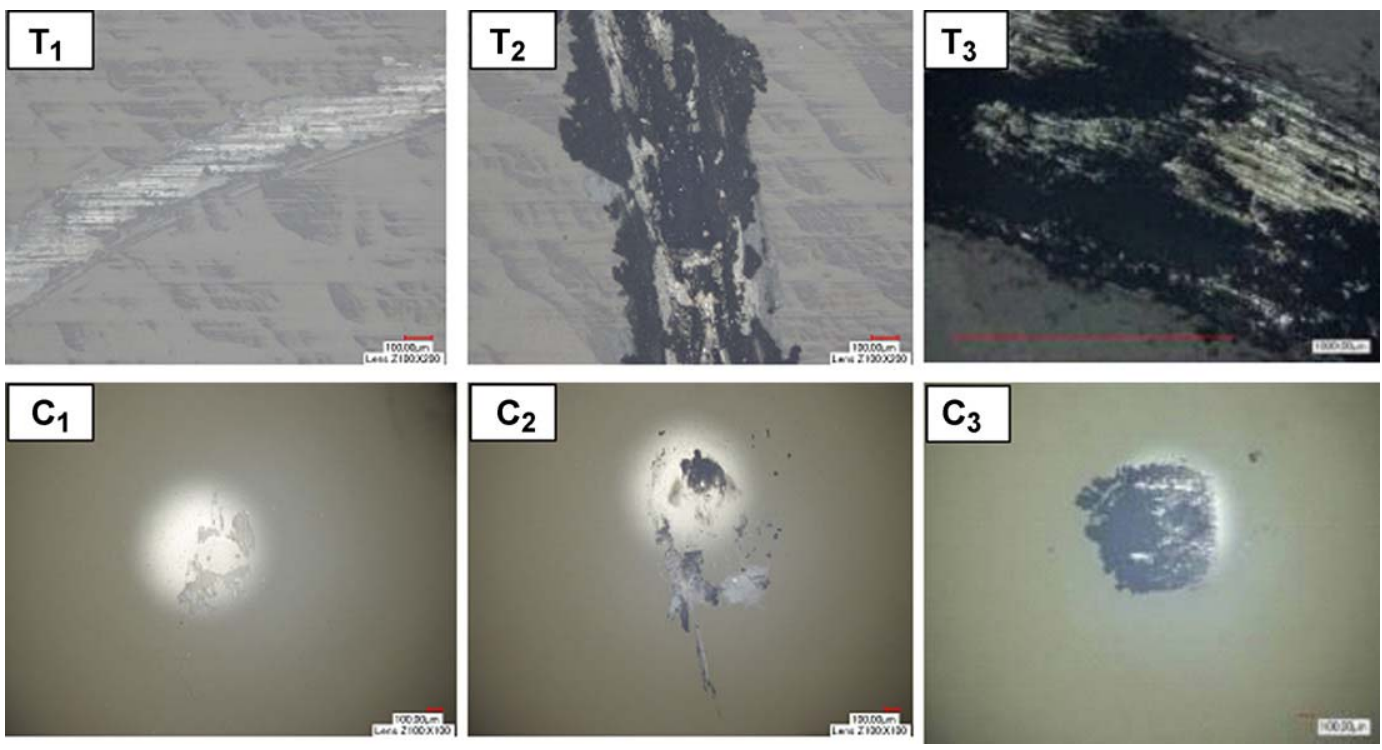

Fig. 14. Facies of the track $(T)$ and the counterface $(C)$ in the first (1), second (2) and third (3) periods for tribological tests with PTFE on top.

Table 5

Characteristics of the track at each period for the PTFE on top surface test and PTFE inside the pore test.

\begin{tabular}{|c|c|c|c|c|c|}
\hline & & Lifetime (cycles) & Depth track $(\mu \mathrm{m})$ & Width track $(\mu \mathrm{m})$ & Wear volume $\left(\mu \mathrm{m}^{3}\right)$ \\
\hline \multirow[t]{3}{*}{ PTFE only on top surface } & First period $(\mu=0.13)$ & 47,000 & $1.1 \pm 0.6$ & 200 & $5.4 \times 10^{6}$ \\
\hline & Second period $(\mu=0.60)$ & 20,000 & $5.5 \pm 1.2$ & 330 & $4.5 \times 10^{7}$ \\
\hline & Third period $(\mu=0.90)$ & 270,000 & $35 \pm 3$ & 900 & $7.8 \times 10^{8}$ \\
\hline \multirow[t]{3}{*}{ PTFE inside the pores } & First period $(\mu=0.17)$ & 200,000 & $0.9 \pm 0.5$ & 200 & $4.4 \times 10^{6}$ \\
\hline & Second period $(\mu=0.60)$ & 30,000 & $3.1 \pm 1$ & 280 & $2.1 \times 10^{7}$ \\
\hline & Third period $(\mu=0.90)$ & 70,000 & $32 \pm 4$ & 770 & $6.0 \times 10^{8}$ \\
\hline
\end{tabular}

Table 6

Intensity ratio $I_{\mathrm{F}} / I_{\mathrm{Al}}$ at the different period of the PTFE on top surface test.

\begin{tabular}{llll}
\hline & First period & Second period & Third period \\
\hline Intensity ratio $I_{\mathrm{F}} / I_{\mathrm{Al}}$ & $>100 \%$ & $7.2 \%$ & $0.1 \%$
\end{tabular}

EDX spectra were carried out on the center of the track after each period in order to analyze the rubbed surface. The intensity ratio $I_{\mathrm{F}} / I_{\mathrm{Al}}$ between the fluorine and the aluminum was calculated (Table 6).

The spectrum of the track during the first period can be seen in Fig. 15a. The carbon and fluorine peaks are strong whereas the aluminum and oxygen peaks are weak. Hence, the counterface is rubbing on PTFE. Then, during the second period (Fig. 15b), the aluminum and the oxygen peaks are strong whereas the carbon and fluorine peaks are weak. The intensity ratio between the fluorine and aluminum peaks is about $7.2 \%$. And finally, when the friction coefficient is $0.90-1.00$ (third period), the spectrum (Fig. 15c) shows a strong aluminum peak and a weak oxygen peak. The fluorine peak disappeared (intensity ratio $I_{\mathrm{F}} / I_{\mathrm{Al}}=0.1 \%$ ). The aluminum substrate is exposed because the PTFE layer and the anodic film have been worn out.

From these results, a first explanation of the friction curves can be proposed. During the first period, the counterface seems to rub against the PTFE on the surface. The depth of the track is only $1.1 \mu \mathrm{m}$ (in agreement with Fig. 8a) and there is only PTFE on the counterface. Then, during the second period, the emergence of black oxide

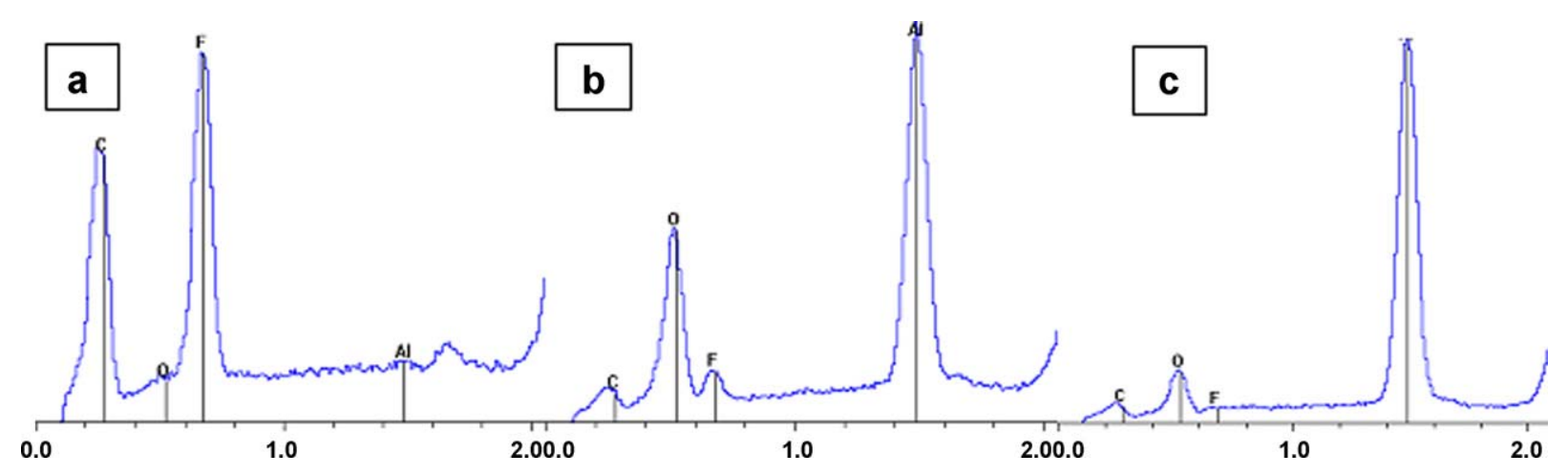

Fig. 15. Localized EDX spectra on the middle of the track at the first (a), second (b) and third test periods (c) of samples with PTFE on top. 

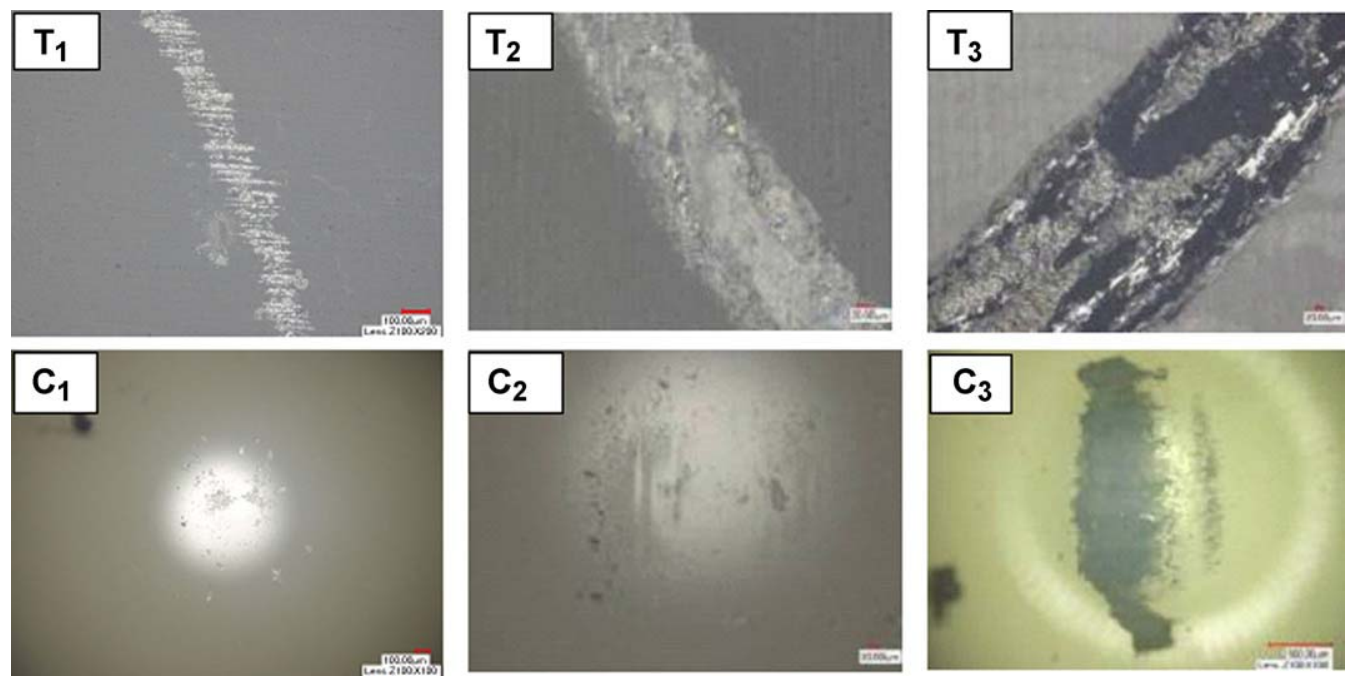

Fig. 16. Facies of the track $(T)$ and the counterface $(C)$ during the first (1), second (2) and third test period (3) with PTFE inside the pores.

fragments on both track and counterface is probably due to the rubbing (depth track: $5.5 \mu \mathrm{m}$ ) on the anodic film (thickness: $10 \mu \mathrm{m}$ ), which explains the increase of the friction coefficient. When the anodic film has been totally worn out (depth track: $35 \mu \mathrm{m}$ ) the friction coefficient remains stable (third period) until the end of the test.

\subsection{Tribological tests on the composite film with superficial and included PTFE}

The anodic films functionalized with PTFE particles on the surface and inside the pores were finally tested and the friction coefficient curve is reported in (Fig. 12). During the first period of the test $(200,000$ cycles $)$, the friction coefficient was low $(\mu=0.17)$, attributed to the PTFE particles on the surface. Then the friction coefficient increased to reach a plateau with a friction coefficient of about $0.50-0.60$ for 8000 cycles and after kept increasing until a value of $0.90-1.00$. In the third period, the friction coefficient remained stable at $0.90-1.00$ (between the friction coefficients of aluminum $(\mu \approx 0.80)$ and anodized aluminum $(\mu \approx 1.1))$ until the end of the test.

The optical views of the track and the counterface were taken at different periods of the test. Fig. 16 shows views of the $\operatorname{track}\left(T_{1}\right)$ and counterface $\left(C_{1}\right)$ during the first period (after 15,000 cycles), corresponding to a friction coefficient of about 0.17 . There is no oxide or metallic fragments and little wear, and PTFE is present on the counterface.

Then, during the second period, when the friction coefficient is stabilized at 0.60 , the facies (Fig. 16) do not show black oxide fragments either in the track or on the counterface. Moreover, PTFE is still present on the counterface. This could be an explanation for the presence of the plateau at $0.50-0.60$ and the extension of the lifetime.

Finally, during the last period (friction coefficient $=0.90-1.00$ ), the aluminum substrate is exposed. Black oxide fragments appeared in the track and on the counterface.

Table 5 presents the different characteristics of the track at each period of the test. Compared to the characteristics of the track with samples with PTFE only on the top surface, the width and depth of the track were lower for each period. Hence, the estimated wear volume was smaller too. For the second period, the wear volume was halved.

EDX spectra were carried out at the center of the track after each period in order to analyze the friction surface. The intensity ratio $I_{\mathrm{F}} / I_{\mathrm{Al}}$ between the fluorine and the aluminum was also calculated (Table 7). During the first period (Fig. 17a), the carbon and fluorine
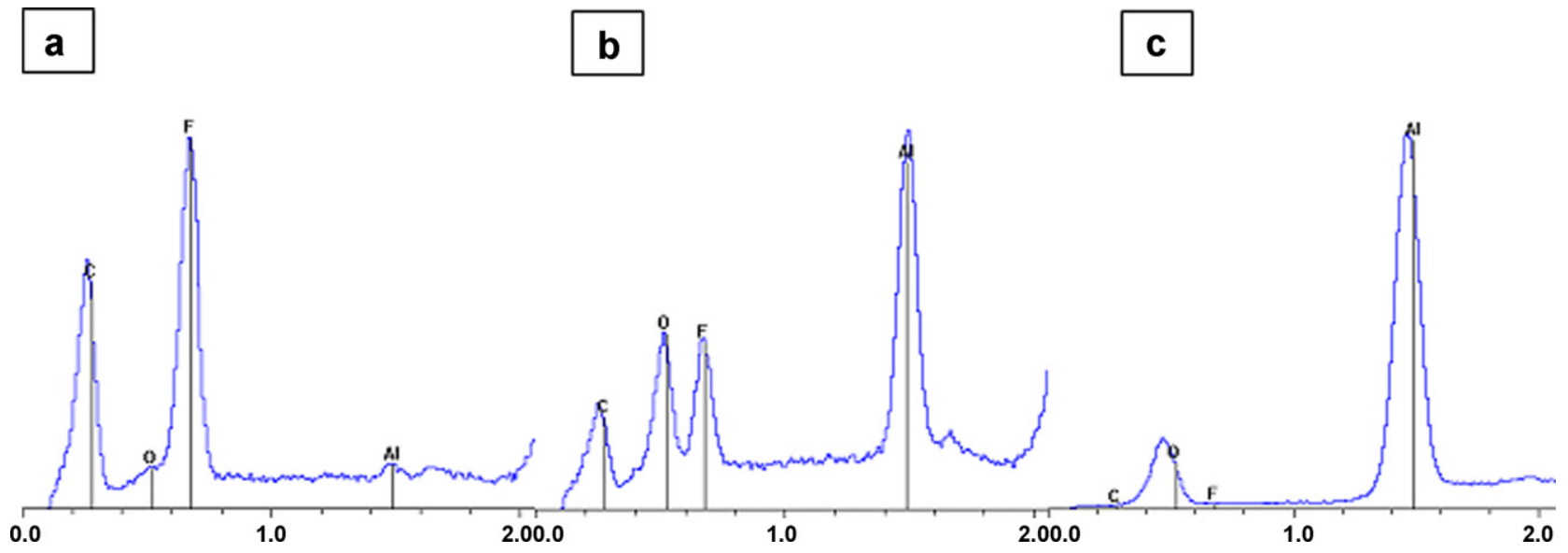

Fig. 17. Localized EDX spectra on the middle of the track at the first (a), second (b) and third test period (c) with PTFE inside the pores. 
Table 7

Intensity ratio $I_{\mathrm{F}} / I_{\mathrm{Al}}$ at each period of the test with PTFE inside the pore.

\begin{tabular}{llll}
\hline & First period & Second period & Third period \\
\hline Intensity ratio $I_{\mathrm{F}} / I_{\mathrm{Al}}$ & $>100 \%$ & $40.1 \%$ & $0.1 \%$ \\
\hline
\end{tabular}

peaks were strong whereas the aluminum and oxygen peaks were weak. So, the counterface was rubbing on PTFE. Then during the second period, the aluminum and the oxygen peaks became strong but the carbon and fluorine peak too (Fig. 17b). This spectrum shows that, during this period, PTFE was still present and the alumina ball was rubbing on the composite PTFE/anodic film. The intensity ratio between the fluorine and the aluminum peaks was about $40.1 \%$.

To finish, when the friction coefficient reached $0.90-1.00$, the spectrum (Fig. 17c) shows a strong aluminum peak and a weak oxygen peak, while the fluorine peak has disappeared. The PTFE layer and the composite film wore out, revealing the aluminum substrate.

\subsection{Comparison between both functionalized anodic films}

To sum up, during the first period of both tribological tests, the friction coefficient was low due to the presence of PTFE coating on the top surface. The counterface rubbed on PTFE and the duration of this first period depended on the thickness of the PTFE layer.

In contrast, during the third period, the anodic film was worn out and the counterface was rubbing on aluminum. The friction coefficient was however higher than on pure aluminum because of the black oxide fragments and wear debris still present in the track and on the counterface.

The main difference between the films was in fact during the second period when the counterface rubbed against the anodic film alone or the composite film. A plateau appeared with a friction coefficient of about $0.50-0.60$ for the composite film. When PTFE particles were included inside the anodic film, there was an increase in the duration (8000 cycles more) of the second period, an increase of the wear resistance (estimated wear volume divided by two) of the composite film and a delayed final increase of the friction coefficient when the film was totally worn out. So, the presence of PTFE particles inside the porous structure is unambiguously responsible for this extension of the lifetime and highlights the benefit of inserting PTFE particles into porous anodic films.

\section{Conclusion}

In this study, we investigated a new way to prepare PTFE-anodic composites supported on 1050 aluminum alloy. Firstly we prepared standard anodic films with a thickness of $10.0 \pm 0.5 \mu \mathrm{m}$ and an average pore diameter of $200 \pm 15 \mathrm{~nm}$, i.e. larger than the particle size $(90 \mathrm{~nm})$ of the PTFE 5070 dispersion and smaller than the size $(220 \mathrm{~nm})$ of the PTFE 3893 dispersion, while the pore density and the porosity were respectively $5.4 \pm 1.5$ pore $\mu \mathrm{m}^{-2}$ and $17.0 \pm 2.5 \%$. Secondly PTFE particles were successfully incorporated directly inside the pores or onto the surface of the anodic films by using an improved sedimentation technique. Then we performed tribological tests and revealed the presence of a plateau on the friction test curve. The incorporated PTFE particles, by delaying the wear of the composite film, enabled a decrease of the total wear by a factor of two and a significant increase of the coating lifetime 75-fold. However, further studies will be necessary to better understand the shear mechanisms of the composite film.

\section{Acknowledgments}

The authors thank Olivier Jaubert for his help in performing the confocal Raman measurements, as well as Barbara Daffos and Pascal Lenormand for the FEG-SEM views. Furthermore, the authors also thank Gustav Jannerfeldt (DuPont de Nemours) for providing PTFE dispersions, and Peter Winterton for his helpful comments.

\section{References}

[1] S. Wernick, R. Pinner, P.G. Sheasby, Surface Treatment and Finishing of Aluminum and its Alloys, vols. 1 and 2, OH/Teddington/ASM International/Finishing Publications, Ltd., England, Metals Park, OH, 1987.

[2] H. Wang, H. Yi, H. Wang, Analysis and self-lubricating treatment of porous anodic alumina film formed in a compound solution, Applied Surface Science 252 (2005) 1662-1667.

[3] H. Kim, D. Kim, W. Lee, S. Cho, J. Hahn, H. Ahn, Tribological properties of nanoporous anodic aluminum oxide film, Surface and Coatings Technology 205 (2010) 1431-1437.

[4] D. Choi, SaLee, SeLee, P. Lee, K. Lee, H. Park, W. Hwang, Dependence of adhesion and friction on porosity in porous anodic alumina films, Scripta Materialia 58 (2008) 870-873.

[5] M. Maejima, K. Saruwatari, M. Takaya, Friction behaviour of anodic oxide film on aluminum impregnated with molybdenum sulfide compounds, Surface and Coatings Technology 132 (2000) 105-110.

[6] M. Gregoire, Hartmann (Tefal) - Perfectionnement aux traitements de surfaces des métaux, Patent FR 1236019 (1959).

[7] TEFAL - Produit en Polytétrafluoroéthylène et son procédé de fabrication, Patent FR 1260025 (1959).

[8] H. Wang, HaWang, Fabrication of self-lubricating coating on aluminum and its frictional behaviour, Applied Surface Science 253 (2007) 4386-4389.

[9] S. Chen, C. Kang, J. Wang, C. Liu, K. Sun, Synthesis of anodizing composite films containing superfine $\mathrm{Al}_{2} \mathrm{O}_{3}$ and PTFE particles on Al alloys, Applied Surface Science 256 (2010) 6518-6525.

[10] J.P. O'Sullivan, G.C. Wood, The morphology mechanism of formation of porous anodic films on aluminum, Proceedings of the Royal Society of London. Series A, Mathematical and Physical Science 317 (1970) 511-543.

[11] G.D. Sulka, S. Stroobants, V. Moshchalkov, G. Borghs, J.-P. Celis, Synthesis of well-ordered nanopores by anodizing aluminum foils in sulfuric acid, Journal of The Electrochemical Society 149 (2002) D97-D103.

[12] G. Zamora, L. Arurault, P. Winterton, R. Bes, Impact of the type of anodic film formed and deposition time on the characteristics of porous anodic aluminium oxide films containing Ni metal, Chemical Papers 65 (2011) 460-468.

[13] ECSS-Q-70-03C - ESA standard, Black-anodizing of metals with inorganic dyes, http://www.ecss.nl/, 2008

[14] Y. Goueffon, G. Aldebert, C. Mabru, L. Arurault, C. Tonon, P. Guigue, Flaking of black anodic films in space environment: ageing and numerical simulation, Mechanics of Materials 45 (2012) 72-82.

[15] P. Ciambelli, L. Arurault, M. Sarno, S. Fontorbes, C. Leone, L. Datas, D. Sannino, P. Lenormand, S. Le Blond Du Plouy, Controlled growth of CNT in mesoporous AAO through optimized conditions for membrane preparation and CVD operation, Nanotechnology 22 (2011) 265613

[16] Rasband, W.S., ImageJ, U.S. National Institutes of Health, Bethesda, Maryland, USA, 1997-2011, http://imagej.nih.gov/ij/.

[17] D.O. Hummel, A. Baum, Atlas of Polymer and Plastics Analysis, Hanser Publishers, Munich, 1991

[18] G. Legeay, A. Coudreuse, J.M. Legeais, L. Werner, A. Bulou, J.Y. Buzare, J. Emery, G. Silly, AF fluoropolymer for optical use: spectroscopic and surface energy studies, comparison with other fluoropolymers, European Polymer Journal 34 (1998) 1457-1465.

[19] M. Wu, M. Ray, K.H. Fung, M.W. Ruckman, D. Harder, A.J. Sedlacek, Stand-off detection of chemicals by UV Raman spectroscopy, Applied Spectroscopy 54 (2000) 800-806.

[20] J. Mihaly, S. Sterkel, H.M. Ortner, L. Kocsis, L. Hajba, É. Furdyga, J. Mink, FTIR and FT-Raman spectroscopic study on polymer based high pressure digestion vessels, Croatica Chemica Acta 79 (2006) 497-501.

[21] Y. Goueffon, L. Arurault, S. Fontorbes, C. Mabru, C. Tonon, P. Guigue, Chemical characteristics, mechanical and thermo-optical properties of black anodic films prepared on 7175 aluminium alloy for space applications, Materials Chemistry and Physics 120 (2010) 636-642.

[22] M.D. Franke, W.R. Ernst, A.S. Myerson, Kinetics of dissolution of alumina in acidic solution, AIChE Journal 33 (1987) 267-273.

[23] F. Keller, M.S. Hunter, D.L. Robinson, Structural features of oxide coatings on aluminum, Journal of The Electrochemical Society 100 (1953) 411-419.

[24] A. Kirchner, K.J.D. MacKenzie, I.W.M. Brown, T. Kemmitt, M.E. Bowden, Structural characterisation of heat-treated anodic alumina membranes prepared using a simplified fabrication process, Journal of Membrane Science 287 (2007) 264-270.

[25] P.P. Mardilovich, A.N. Govyadinov, N.I. Mukhurov, A.M. Rzhevskii, R. Paterson, New modified anodic alumina membranes Part I. Thermotreatment of anodic alumina membranes, Journal of Membrane Science 98 (1995) 131-142. 
[26] P. Bocchetta, C. Sunseri, G. Chiavarotti, F. Di Quarto, Microporous alumina membranes electrochemically grown, Electrochimica Acta 48 (2003) 3175-3183.

[27] "Raman Instrumentation - HORIBA», s.d., http://www.horiba.com/fr/scientific/ products/raman-spectroscopy/tutorial-faqs/raman-tutorial/ramaninstrumentation/.

[28] G.Q.Lu, X.S. Zhao, Nanoporous Materials - Science and Engineering, Imperial College Press, London, 2004
[29] P.A. Kralchevsky, K. Nagayama, Capillary forces between colloidal particles, Langmuir 10 (1994) 23-36.

[30] K. Nagayama, Two-dimensional self-assembly of colloids in thin liquid films, Colloids and Surfaces A 109 (1996) 363-374

[31] W.G. Sawyer, K.D. Freudenberg, P. Bhimaraj, L.S. Shadler, A study on the friction and wear behavior of PTFE filled with alumina nanoparticles, Wear 254 (2003) 573-580. 